\title{
Analysis on the Causes and Countermeasures of the Loss of supernumerary employment in public Universities
}

\author{
Ge Yiyao, Du yaqi \\ Yunnan University of Finance and Economics, \\ Kunming, Yunnan, P.R. China \\ 976934322@qq.com
}

\begin{abstract}
The supernumerary employment is a product of the personnel management of the party, government organs, enterprises and institutions of our country. This paper clearly stipulates the method for preparation of supernumerary employment management, understands the major problems existing in the establishment of supernumerary employment, clarifies the preparations for improving the management of supernumerary employment, improves the supernumerary employment management system, and improves the efficiency and quality of running a school which is aim to make the non-staff involved work equally with those in the organization to achieve a win-win situation for personal realization and school development. The colleges and universities are set up scientifically, the system is improved, the design is flexible, and the management is standardized. The colleges and universities are constantly strengthening the management and construction of the supernumerary employment contract system.
\end{abstract}

Keywords-Universities; supernumerary employment; causes of loss; countermeasures

\section{INTRODUCTION}

With the continuous development of social economy, the social reforms in various departments of colleges and universities continue to deepen. Regardless of the quantity and quality, employees in the original establishment cannot gradually meet the needs of school development. Temporary workers from the labor market has gradually become a major component of the university's human resources. Higher-educated teachers in institutions of higher learning refer to those full-time teachers who sign labor contracts with public institutions of higher learning, engage in teaching and research in public institutions of higher learning, and do not belong to public institutions of higher learning. It is up to the teachers whether move to the seat of the universities or not. Their files are usually left to be escrowed by the talent service center under the government of the university.

The loss of supernumerary employment will not only affect the stability of school teaching and the sustainability of teaching team construction, but also affect the stability of other non-compiling teachers' work sentiments, and may even result in "cocoon effects" and "chain reaction". The strength of the university faculty is reflected not only on the individual well-known teachers, but also in the ever-growing and effective teaching teams. Due to the high turnover rate of temporary workers, there are also teachers, professional leaders, heads of teaching units, age-related faults, and education "succeeding" in schools where teachers have a high proportion of teachers. There are no people in places that are in short supply. The overall development of the school is affected.

\section{THE SITUATION OF THE PREPARATION OF SUPERNUMERARY STAFF IN UNIVERSITY}

The employment of contracted personnel in colleges and universities is mainly concentrated in the logistics departments, such as security, greening, and cleaning. Those personnel do not have professional backgrounds, and their quality is low. The service quantity and quality are difficult to meet the needs of the school's continuous development. There are also some faculty and assistant departments that use staff for the preparation and contracting of foreign companies. Although these staff generally have certain professional background, they still feel unsatisfactory with their low benefits for the reasons that they are not prepared.That is why the enthusiasm and professionalism of these people are difficult to raise. Another issue is that some of the formal staff are occupied and not working, and the work is pushed to the staff of the supernumerary contract (Dou, 2015), which easily leads to the preparation of routine work. Because of the influence of internal and external environmental factors, teachers often fluctuate psychologically. Due to the fluctuate in thoughts and emotions, they quit and resign frequently. Some of the non-compiling teachers unexpectedly broke up during the semester, and college-related departments and personnel departments were caught off guard.

At present, the preparation of foreign teachers in colleges and universities in our country is immersed in the dilemma of unequal pay for equal work, unequal development opportunities, and low awareness of identity and self-worth. Colleges and universities in the preparation of the introduction of supernumerary employment, the introduction of high-quality teachers outside the preparation difficulties, the responsibility and enthusiasm of the preparation of the work of foreign teachers is difficult to mobilize, its high turnover rate, teaching stability and team building has been affected, resulting in staff management and service workload Increase. Temporary workers caused a great psychological impact. Many employees have been working in school for many years and have regarded themselves as a part of the school. They have had a sense of belonging to the school and their jobs. However, the change in labor relations force them to face the obstacles in their self-positioning and cannot 
correctly recognize this three-way relationship, which result in the lack of awareness of active working units. Providing labor quality and efficiency has a great influence. Because there is no support from emotional factors, it will have an impact on the stability of the work of the workers. Taking labor remuneration as the main driving force for work, frequent job-hopping is more common.

\section{REASONS FOR THE LOSS OF SUPERNUMERARY}

\section{EMPLOYMENT}

The Labor Law stipulates that employers should pay the same amount of remuneration for workers who perform the same work, pay the same amount of labor, and obtain the same performance. The preparation of temporary workers and the permanent wokers in the same job, but because of the different status within the system, they can get different labor compensation. The teachers who are temporary workers cannot enjoy the uniform government-issued fiscal salary, teacher allowance, monetization housing subsidy and other relevant allowances and subsidies. In addition, there are also large differences in the welfare benefits. In individual colleges and universities, the preparation of teachers outside the school even failed to fully have the Social Insurance and Housing Fund Insurance. As a result of unfair treatment, supernumerary staff will be too impatient to think that they are outside the system and deeply feel that they are "low-class" in front of regular teachers. They are trying hard to translate their personal efforts into preparations. Teachers, on the other hand, will slowly "identify" themselves in this dilemma. It is difficult for the temporary teachers to perceive the value of the self through the aforementioned factors. They dare not to reveal their different opinions and do not want to participate in the activities of democratic life in colleges and universities.

The overall level of wages and salaries for temporary workers is not high, the structure is single, and there are significant differences in the treatment of different types of posts. According to the survey, there is a large gap between the establishment of externally-employed personnel in colleges and universities and similar personnel in other sectors of society. In the salary structure of off-staff, basic wages are included, performance wages, allowances, and bonuses are not mentioned. There is a large gap between the different types of jobs (Dou, 2015). In 2017, the average wage of non-standard staff in our school is less than RMB 3,000. Article 12 of the Labor Contract Law stipulates that the labor contract is divided into fixed-term labor contracts, no fixed-term labor contracts and deadlines for completing certain work tasks. Labor Contract. This means that all employees should sign labor relations with employers and enjoy the same treatment. The difference is only the duration of the labor contract. Therefore, the preparation of external staff should enjoy the same rights as formal staffing. The archives management department should change its concepts, establish sound personnel files for the development of externally employed personnel, develop archives information resources, preserve the evidence of rights and interests, and give full play to the social service functions of personnel files.

\section{REDUCING THE LOSS OF SUPERNUMERARY}

\section{EMPLOYMENT IN PUBLIC UNIVERSITIES}

We must strengthen the reform of the distribution system, set the salary at the post, determine the salary, assign the distribution system according to work, and promote the key to the rational flow and allocation of employees. Any important decision must be linked to performance. According to Maslow's Hierarchy of Needs, satisfying people's needs is the most direct and effective way to motivate employees to work hard. The incentive function of the distribution system is that it is an important basis for fully satisfying employees' various needs, and it gives employees a sense of security both physically and psychologically, thereby enhancing their sense of belonging and honor to the unit. At present, the pattern of income distribution among supernumerary employment in various colleges and universities in Chongqing is single and the phenomenon of equalitarianism is serious. The main performance is that the vast majority of employees' income is at the city's minimum level, which is insufficient incentive. This kind of distribution system, to some extent cannot mobilize its enthusiasm. In some colleges and universities, the implementation of the reform of the entity distribution system has, to a certain extent, mobilized the enthusiasm of the employees, but no matter what kind of wage distribution system has limitations, it is not conducive to reflecting the differences in the ability and labor contribution between the same position, may Cause short-term behaviors of managers and employees. The feasible methods are: standardizing service procedures, scientifically defining job responsibilities, rationally arranging working hours, and widening the income gap. Performance managers should also be fair towards rewards and punishments, and correct decisions. Electing people and employing people to have a degree, so that dedicated, talented, excellent comrades engaged in higher income coefficient work, and the poor performance of the comrades to lower the coefficient of the post. No one can implement a tenure system for those who have already taken up posts. For comrades who are not flexible enough to play a key role or those who do not have strong abilities, they should be adjusted in time so that the comrades with strong abilities can serve as the backbone of the department. This not only puts pressure on the backbone, prompts them to use their brains and work hard, but also allows other workers to see hope and head. For example, the logistics community center can set different job factors according to the size of the area under the jurisdiction of the department, the number of employees and the size of each building and building area, and each person can compete for the job according to their own ability. The post, the implementation of post-quantitative assessment, dynamic management, promote equal payment for equal work, through policy guidance, for the preparation of external teachers to expand, use and compile and expand the development of space, reduce the number of temporary workers, at the same time, the development of supernumerary teachers to strengthen human care To create a harmonious environment for its development, based on the use of incentive theory, improve the preparation of supernumerary employment management system, improve the school's work efficiency and quality, so that temporary workers and the regular staff within the same job. Only by firmly grasping the concept of human resource management, using the method of human resources management correctly, and using talented people and distribution according to work can we fully exert the incentive function of the distribution system, promote the rapid and better development of the service industry of the university, and achieve a win-win situation for personal value and school development.

REFERENCE 
[1] Niu Y(2016), Research on the Preparation of Salary for Foreign Workers in Colleges and Universities, Cooperation Economy and Science and Technology,vol.11,pp136-137. (In Chinese)

[2] Wang GJ(2015),The Problems and Countermeasures of Non-Completed Teacher Management in Colleges and Universities, Theory and Practice of Education,vol.35,pp18-20. (In Chinese)

[3] Dou YB(2015),"The people's livelihood first" and the establishment of external staff management in universities, Human Resource Management,pp150-151. (In Chinese)
[4] Lin ZK(2012),Discussion on the Problems Related to Compiling Workers in Foreign Labor Contract System in Colleges and Universities,Journal Of Jilin Business And Technology College,vol. 28, no. 1,pp123-125. (In Chinese)

[5] Wang YF(2013),Based on SWOT analysis model to explore the management mode of extracurricular employment in colleges and universities,Journal of Yunnan Agricultural University,vol.53,pp44-48. (In Chinese) 